\title{
MIKROEMULSIFIKASI FRAKSI TIDAK TERSABUNKAN DISTILAT ASAM LEMAK MINYAK SAWIT
}

\author{
[Microemulsification of Unsaponifiable Fractions of Palm Fatty Acid Distillate] \\ Teti Estiasih ${ }^{1 / \star}$, Kgs. Ahmadi ${ }^{2)}$, dan Layly Alifatur Rizqiyah¹) \\ 1) Program Studi IImu dan Teknologi Pangan, Fakultas Teknologi Pertanian, Universitas Brawijaya, Malang \\ 2) Jurusan Teknologi Industri Pertanian, Fakultas Pertanian, Universitas Tribhuwana Tunggadewi, Malang
}

Diterima 01 Oktober 2015 / Disetujui 24 Desember 2015

\begin{abstract}
Palm fatty acid distillate (PFAD) is a by-product of palm oil refining that contains valuable bioactive compounds such as phytosterols, tocopherol, tocotrienols, and squalene which acummulates in unsaponifiable fraction (USF). In emulsion form, USF will be convenient and easy to use as food supplements or fortificants. Microemulsion is a type of emulsion that has stable droplet sizes of less than $10 \mu \mathrm{m}$. Hence, the best emulsifier for USF microemulsion is important to be determined. The USF microemulsion was prepared by homogenizing the sample mixtures at $12.000 \mathrm{rpm}$ for $20 \mathrm{~min}$ at USF concentration of $10 \%(\mathrm{w} / \mathrm{V})$ with lecithin and tween 80 as the emulsifiers at concentratiosn of 0.5, 1.0, and $1.5 \%$ (w/v). The microemulsions were analyzed for their viscosity, stability, and particle size distributions, as well as microstructures. The results showed that characteristics of microemulsion were affected by emulsifier types and concentrations. Tween 80 produced better microemulsion than lecithin as indicated by more stable emulsions, smaller droplet sizes, and narrower ranges of dropletsize distributions. Increasing lectihin concentrations resulted in a narrower droplet size distribution but the average droplet size was not always smaller. Conversely, increasing tween 80 concentrations increased the average droplet sizes and ranges of particle size distributions. The most suitable emulsifier for USF microemulsion was tween 80 at concentration of $0.5 \%$. This microemulsion contained bioactive compounds derived from USF, namely vitamin $E$ (mainly tocotrienols), phytosterols, and squalene.
\end{abstract}

Keywords: bioactive compounds, emulsifier, microemulsion, partlcle size distribution, palm fatty acid distillate

\section{ABSTRAK}

Distilat asam lemak minyak sawit (DALMS) merupakan hasil samping pengolahan minyak goreng yang mengandung senyawa bioaktif fitosterol, tokoferol, tokotrienol, dan skualen yang sangat berharga. Komponen-komponen tersebut terakumulasi pada fraksi tidak tersabunkan (FTT). Untuk memperluas pemanfaatannya sebagai suplemen dan fortifikan pangan, FTT dapat diubah menjadi emulsi sehingga mudah untuk ditangani dan digunakan. Mikroemulsi merupakan bentuk emulsi dengan ukuran droplet kurang dari $10 \mu \mathrm{m}$ sehingga lebih stabil. Akan tetapi, jenis pengemulsi yang tepat untuk mikroemulsi FTT masih perlu untuk ditentukan. Mikroemulsi FTT dibuat pada konsentrasi $10 \%$ (b/v) dengan jenis pengemulsi tween 80 atau lesitin pada konsentrasi 0,$5 ; 1,0 ;$ dan 1,5\% (b/v) menggunakan homogenizer pada kecepatan 12.000 rpm selama 20 menit. Mikroemulsi yang dihasilkan dianalisis meliputi viskositas, stabilitas, distribusi ukuran partikel, dan mikrostruktur. Hasil penelitian menunjukkan karakteristik mikroemulsi FTT dipengaruhi oleh jenis dan konsentrasi pengemulsi. Tween 80 lebih mampu menghasilkan mikroemulsi yang lebih baik dibandingkan lesitin. Performa mikroemulsi yang baik ditunjukkan oleh mikroemulsi yang stabil, interval distribusi ukuran partikel yang sempit, serta ukuran droplet emulsi yang kecil. Peningkatan konsentrasi lesitin menghasilkan mikroemulsi dengan distribusi ukuran droplet yang lebih sempit, sedangkan rata-rata ukuran droplet tidak selalu lebih kecil. Sebaliknya, peningkatan konsentrasi tween 80 menyebabkan rata-rata ukuran droplet dan interval distribusi ukuran droplet yang lebih besar. Mikroemulsi terbaik menggunakan pengemulsi tween 80 dengan konsentrasi 0,5\%. Mikroemulsi ini mengandung senyawa bioaktif yang berasal dari FTT berupa vitamin E (terutama tokotrienol), fitosterol, dan skualen.

Kata kunci: distribusi ukuran partikel, distilat asam lemak sawit, mikroemulsi, pengemulsi, senyawa bioaktif

*Penulis Korespondensi:

E-mail: teties@yahoo.co.id 


\section{PENDAHULUAN}

Indonesia mempunyai potensi senyawa bioaktif yang besar dan berlimpah yaitu hasil samping pengolahan minyak goreng berupa distilat asam lemak minyak sawit (DALMS). DALMS mengandung asam lemak dan gliserida $96,1 \%$, serta komponen minor bioaktif seperti tokoferol dan tokotrienol $0,48 \%$, fitosterol $0,37 \%$, skualen $0,76 \%$, dan hidrokarbon lain 0,71\% (Gapoor et al., 2002). Pemanfaatan DALMS selama ini difokuskan sebagai sumber asam lemak bukan sebagai sumber senyawa bioaktif. Komponen bioaktif dalam DALMS merupakan komponen yang berada pada fraksi tidak tersabunkan (FTT) (Khatoon et al., 2010). Saponifikasi DALMS pada kondisi optimum menghasilkan FTT yang mengandung tokoferol 0,06\%, tokotrienol 0,73\%, fitosterol 9,18\%, dan skualen 1,14\% (Estiasih et al., 2013). Untuk memperluas kegunaan FTT DALMS, maka perlu dikaji teknik untuk stabilisasi dan pengubahan bentuk FTT yang kental menjadi cair melalui teknik emulsifikasi. Sistem emulsi minyak dalam air banyak digunakan dalam industri pangan dan farmasi dan merupakan pembawa bioaktif lipofilik (Nik et al., 2011). Di antara jenis emulsi, mikroemulsi mempunyai sifat yang unik yaitu tegangan antarmuka yang rendah, lebih stabil, dan mempunyai kemampuan pelarutan yang tinggi (Lu et al., 2012). Mikroemulsi merupakan emulsi dengan ukuran globula kurang dari $10 \mu \mathrm{m}$ (Madaan et al., 2014). Emulsi dapat digunakan sebagai pembawa senyawa bioaktif karena dapat secara mudah ditambahkan pada produk pangan (Lu et al., 2012).

Pengemulsi mempunyai bagian hidrofobik dan hidrofilik dalam struktur molekulnya sehingga dapat terkonsentrasi pada antarmuka minyak-air dan menurunkan tegangan permukaan. Pengemulsi memfasilitasi pembentukkan emulsi selama proses homogenisasi (Cabezas et al., 2012). Mikroemulsi dapat dibuat dengan menggunakan formulasi surfaktan yang sesuai (Phan et al., 2011). Untuk menghasilkan emulsi dengan ukuran droplet yang kecil, emulsi kasar dihomogenisasi dua kali menggunakan homogenizer tekanan tinggi (Imai et al., 2008).

Pengemulsi yang tepat sangat penting dalam menstabilkan sistem emulsi. Pengemulsi akan berada pada antarmuka droplet dan fase akueous dalam sistem emulsi (Tan dan Nakajima, 2005; Tadros, 2013). Pengemulsi yang banyak digunakan di industri pangan adalah lesitin (McClements, 2015) dan tween 80 (Hasenhuetti, 2008). Lesitin komersial merupakan campuran fosfolipid yang tidak larut aseton dan komponen minor lainnya seperti trigliserida dan karbohidrat (Cabezas et al., 2012). Campuran tidak larut aseton terdiri dari fosfatidilkolin, fosfatidiletanolamin, fosfatidilinositol, dan komponen minor meliputi asam fosfatidat, karbohidrat, dan trigliserida (Cabezas et al., 2009); sedangkan tween merupakan polioksietilen sorbitan (Mahmood dan Koofee, 2013). Selain jenis, konsentrasi pengemulsi sangat mempengaruhi stabilitas emulsi. Konsentrasi pengemulsi yang tinggi menyebabkan destabilisasi emulsi akibat dinamika antara pengemulsi yang teradsorpsi dan yang tidak teradsorpsi pada antarmuka (McClements, 2015), sedangkan pada konsentrasi rendah jumlah pengemulsi tidak cukup untuk menutup wilayah antarmuka sehingga emulsi menjadi tidak stabil (Tadros, 2013). Oleh karena itu, pada penelitian ini dikaji jenis pengemulsi dan konsentrasinya yang tepat dalam menstabilkan mikroemulsi FTT dari DALMS.

\section{BAHAN DAN METODE}

\section{Bahan}

Bahan baku distilat asam lemak minyak sawit (DALMS) diperoleh dari industri pengolahan CPO PT. Salim Ivomas Pratama Surabaya.

\section{Pembuatan fraksi tidak tersabunkan (FTT)}

Pembuatan FTT mengacu pada hasil penelitian sebelumnya (Estiasih et al., 2013) dengan menggunakan bahan kimia teknis berupa heksana, $\mathrm{KOH}$, etanol, dan vitamin $\mathrm{C}$ (Bratachem, Indonesia).

\section{Pembuatan mikroemulsi (Modifikasi Imai et al., 2008)}

Pengemulsi lesitin (Bratacehm, Indonesia) atau tween 80 (Bratachem, Indonesia) dilarutkan dalam akuades sehingga diperoleh konsentrasi 0,$5 ; 1,0$; dan $1,5 \%$ (\% b/v akuades) dan volume dibuat 50 $\mathrm{mL}$. FTT sebanyak $10 \%$ (b/v) ditambahkan dan kemudian dilakukan homogenisasi dengan ultraturax (Ika T-18 Basic, Jerman) pada kecepatan 12.000 rpm selama 20 menit sampai terbentuk mikroemulsi.

\section{Rancangan percobaan dan analisis data}

Rancangan percobaan yang digunakan pada penelitian ini adalah rancangan acak lengkap dua faktor tiga kali ulangan. Data viskositas dan turbiditas dianalisis ragam dengan Anova dan jika perlakuan menunjukkan pengaruh yang nyata, dilakukan analisis lanjut dengan beda nyata jujur (BNT). Analisis yang dilakukan pada DALMS dan FTT meliputi tingkat oksidasi dengan bilangan peroksida (Kim, 2005) dan bilangan anisidin (IUPAC, 1979), kadar asam lemak bebas (AOCS, 1990), dan senyawa bioaktif vitamin $E$ (tokoferol dan tokotrienol), fitosterol, dan skualen. Analisis mikroemulsi meliputi viskositas (Kapillar Viskosimeter, Schoott Gerate), stabilitas terhadap pemisahan, dan distribusi ukuran partikel, dan mikrostruktur dengan scanning electron microscope (SEM). 


\section{Analisis skualen (Mendez et al., 2003)}

Analisis skualen menggunakan GC MS (GCMS-QP2010S Shimadzu, Jepang) dengan derivatisasi metode Mendez et al. (2003). Sebanyak $1 \mu \mathrm{L}$ sampel yang sudah diderivatisasi diinjeksikan pada GC MS dengan kolom (AGILENT DB-1, USA) $30 \mathrm{~m}$, diameter internal $0,25 \mathrm{~mm}$, gas pembawa helium dan ionisasi El $70 \mathrm{Ev}$. Kondisi operasional GC adalah suhu $80^{\circ} \mathrm{C}$, suhu injektor $310^{\circ} \mathrm{C}$, tekanan $16,5 \mathrm{kPa}$, kecepatan aliran $80,0 \mathrm{~mL} / \mathrm{menit}$, kecepatan aliran dalam kolom $0,50 \mathrm{~mL} /$ menit, kecepatan linier 26,1 cm/detik, kecepatan gas pendorong 3,0 $\mathrm{mL} / \mathrm{menit}$ dan rasio split 153,0. Suhu awal adalah $80^{\circ} \mathrm{C}$ dan ditahan selama 5 menit. Suhu ditingkatkan dengan kecepatan $10^{\circ} \mathrm{C} /$ menit sampai $305^{\circ} \mathrm{C}$ dan ditahan selama 25 menit. Analisis MS dilakukan dengan suhu sumber ion $250^{\circ} \mathrm{C}$, suhu interface $310^{\circ} \mathrm{C}$, solvent cut time 80 menit, kecepatan scan 1.250 , mulai $\mathrm{m} / \mathrm{z} 28,0$ dan berakhir $\mathrm{m} / \mathrm{z} \quad 600,0$. Standar yang digunakan adalah standar skualen dari Sigma-Aldrich, Singapura.

\section{Analisis fitosterol (Khatoon et al., 2010)}

Analisis dilakukan dengan menggunakan HPLC Shimadzu LC-20AD (Jepang), kolom Shimpack VPODS $250 \mathrm{~mm} \times 4,6 \mathrm{~mm}$, kecepatan aliran 1,3 $\mathrm{mL} /$ menit, detektor UV/VIS SPD-20A pada panjang gelombang $206 \mathrm{~nm}$, fase gerak metanol:akuabides (99:1) dan standar fitosterol ( $\beta$-sitosterol, kampesterol, stigmasterol) (Stigma-Aldrich, Singapura). Sampel FTT ditimbang sejumlah $1 \mathrm{mg}$ dan ditambah dengan etanol $1 \mathrm{~mL}$ lalu disaring dan volume yang diinjeksikan $20 \mu \mathrm{L}$.

\section{Analisis vitamin E}

Sampel FTT ditimbang sejumlah $1 \mathrm{mg}$ dan ditambah dengan etanol $1 \mathrm{~mL}$ lalu disaring. Analisis dilakukan menggunakan HPLC (Shimadzu LC20AD, Jepang) dengan kolom Shimpack VP-ODS $250 \mathrm{mmx} 4,6 \mathrm{~mm}$, kecepatan aliran $1,3 \mathrm{~mL} /$ menit, detektor UV/VIS SPD-20A pada panjang gelombang $295 \mathrm{~nm}$, fase gerak metanol:akuabides (95:5), dan volume injeksi $20 \mu \mathrm{L}$ dengan standar tokoferol ( $\alpha$ tokoferol) (Santa Cruz Biotechnology, USA) tooktrienol ( $\alpha, \delta, \quad \gamma$-tokotrienol) (Santa Cruz Biotechnology, USA).

\section{Analisis stabilitas emulsi (modifikasi Ogawa et al., 2004)}

Sampel sebanyak $3,5 \mathrm{~g}$ diencerkan sampai konsentrasi fase terdispersi $0,0005 \%$ kemudian dimasukkan ke dalam kuvet dan disimpan pada suhu $30^{\circ} \mathrm{C}$ selama 7 hari. Kekeruhan diukur dengan spektrofotometer UV-Vis (20D Plus, LaboMed, USA) pada panjang gelombang $600 \mathrm{~nm}$. Droplet dalam emulsi akan bergerak ke atas karena gravitasi. Peningkatan kekeruhan mengindikasikan bahwa droplet bergerak ke atas karena ketidakstabilan.
Persentase (\%) turbiditas diperoleh dari 2,303 x absorbansi.

\section{Analisis mikrostruktur dengan scanning electron microscope (SEM)}

Analisis mikrostruktur dilakukan menggunakan SEM (FEI tipe Inspect S50, EDAX AMETEK, USA). Sampel emulsi dikeringkan dengan cara menghilangkan air menggunakan hot plate kemudian sampel diletakkan dalam sample holder yang sudah diberi double side carbon tape. Coating dilakukan dengan menggunakan sputter coater (Emitech SC7620, UK) agar sampel dilapisi dengan Au-Pd. Pengukuran dilakukan pada perbesaran 20.000 kali.

\section{Analisis ukuran partikel}

Analisis ukuran partikel dilakukan dengan menggunakan Particle Size Analyzer (PSA, CILAS 1090, USA). Sampel diencerkan dengan akuades, dengan perbandingan sampel:akuades 1:5. Kemudian dilakukan pengocokan manual supaya sampel homogen. Kemudian sampel dimasukkan ke dalam chamber filling nozzle untuk pengukuran.

\section{HASIL DAN PEMBAHASAN}

\section{Karakteristik kimia DALMS dan fraksi tidak tersabunkan \\ DALMS mempunyai karakteristik seperti pada} Tabel 1. Kadar asam lemak bebas (ALB) merupakan indikator kadar fraksi tidak tersabunkan (FTT). Data pada Tabel 1 menunjukkan bahwa DALMS yang dihasilkan mempunyai kadar asam lemak bebas yang memenuhi standar DALMS dari Palm Oil Research Institute of Malaysia (PORIM) (yaitu minimum $70 \%$. Asam lemak bebas pada FTT merupakan asam lemak yang tidak tersabunkan pada proses saponifikasi. Kadar asam lemak bebas pada FTT merupakan residu asam lemak yang tidak tersabunkan dan dalam FTT menurun drastis menjadi 4,06\% karena sebagian besar asam lemak tersaponifikasi menjadi fraksi tersabunkan. Keberadaan asam lemak bebas ini pada FTT tidak diinginkan karena kadar asam lemak yang tinggi menunjukkan proses saponifikasi tidak sempurna.

Data Tabel 1 menunjukkan tingkat oksidasi DALMS dan FTT berupa bilangan peroksida (produk oksidasi primer) dan bilangan anisidin (produk oksiasi sekunder). Produk oksidasi minyak bersifat volatil sehingga menguap pada proses deodorisasi. Pada tahap distilasi untuk mengambil kembali asam lemak bebas, kemungkinan produk oksidasi minyak hanya sebagian yang mengalami kondensasi sehingga kadarnya dalam DALMS cukup rendah. FTT mempunyai tingkat oksidasi yang lebih rendah daripada DALMS. Pada proses pembuatan FTT, diduga produk oksidasi primer dan sekunder ada 
fraksi tersabunkan sehingga kadarnya pada FTT lebih rendah. Hal ini menguntungkan jika FTT DALMS akan dimanfaatkan sebagai sumber senyawa bioaktif karena produk oksidasi lipid yang berefek negatif terhadap kesehatan berada pada kadar yang rendah.

Tabel 1. Karakteristik kimia DALMS dan FTT

\begin{tabular}{lcc}
\hline \multicolumn{1}{c}{ Karakteristik } & DALMS & FTT \\
\hline $\begin{array}{l}\text { Kadar asam lemak } \\
\text { bebas }(\%)\end{array}$ & $80,74 \pm 0,49$ & $4,06 \pm 0,70$ \\
Bilangan peroksida & $4,74 \pm 0,78$ & $3,31 \pm 0,35$ \\
(mek $\mathrm{O}_{2} / \mathrm{kg}$ ) & & \\
Bilangan anisidin & $2,79 \pm 0,67$ & $2,32 \pm 0,20$ \\
Rendemen & & $2,17 \pm 0,39$ \\
\hline
\end{tabular}

\section{Kadar senyawa bioaktif DALMS dan FTT}

Senyawa bioaktif yang terdeteksi dalam DALMS adalah vitamin $E$, fitosterol, dan skualen. Loganathan et al. (2009) menunjukkan bahwa minyak sawit mengandung vitamin E 600-1000 ppm, fitosterol 300-620 ppm, karotenoid 500-700 ppm, skualen 250-540 ppm, fosfolipid 20-100 ppm, koenzim Q10 10-80 ppm, dan polifenol 40-70 ppm. Tabel 2 menunjukkan bahwa secara umum senyawa bioaktif yang paling banyak terdapat dalam DALMS adalah vitamin E. Distillate deodorizer dari berbagai jenis minyak nabati bervariasi dengan komponen dominan dalam distillate deodorizer minyak kedelai adalah fitosterol (Khatoon et al., 2010), minyak canola dan biji bunga matahari adalah fitosterol (Naz et al., 2014), minyak jagung adalah fitosterol (Majoni dan Wang, 2010), sedangkan Wan et al. (2008) menyatakan bahwa minyak kedelai didominasi tokoferol. Jika dibandingkan dengan distillate deodorizer minyak lain, kadar tokoferol dalam minyak canola dan biji bunga matahari adalah 3,77-6,59\% dan 6,51\% (Naz et al., 2014), sedangkan DALMS mengandung vitamin $\mathrm{E} 4,77 \%$. Vitamin $\mathrm{E}$ dalam minyak canola dan biji bunga matahari didominasi tokoferol (Naz et al., 2014) sedangan DALMS didominasi tokotrienol. Fitosterol dalam distillate deodorizer minyak kedelai adalah 6-10\% atau 60.000-100.000 ppm (Khatoon et al., 2010) sedangkan penelitian ini menunjukkan kadar fitosterol DALMS 6.400 ppm. $\mathrm{Naz}$ et al. (2014) menunjukkan kadar skualen dalam distillate deodorizer minyak canola dan biji bunga matahari adalah 3,49 dan $4,51 \%$, sedangkan DALMS menunjukkan kadar skualen 0,14\%. Dapat disimpulkan bahwa DALMS mengandung senyawa bioaktif yang lebih rendah dibandingkan distillate deodorizer minyak lain. Kadar senyawa bioaktif yang lebih rendah dalam DALMS dibandingkan distillate deodorizer minyak nabati lain disebabkan kadar asam lemak bebas DALMS yang tinggi sehingga komponen non asam lemak termasuk senyawa bioaktif menjadi rendah. Benites et al. (2009) melaporkan kadar asam lemak bebas dalam distillate deodorizer minyak kedelai adalah $53 \%$, sedangkan DALMS mengandung asam lemak bebas sekitar $80 \%$.

Data pada Tabel 2 menunjukkan bahwa pembuatan FTT dari DALMS meningkatkan konsentrasi senyawa bioaktif. FTT mengandung vitamin $E$ sebesar 34,24\% $(342,4 \mathrm{mg} / \mathrm{g})$, kadar fitosterol sebesar 15,48\% (154,8 $\mathrm{mg} / \mathrm{g})$, dan kadar skualen sebesar 2,10\% (21,0 mg/g). Peningkatan ini terjadi akibat senyawa bioaktif terakumulasi dalam fraksi tidak tersabunkan. Keberadaan senyawa bioaktif berbagai komponen ini menunjukkan bahwa FTT kaya bioaktif yang dapat saling bersinergi untuk memberikan efek positif seperti peningkatan produksi ASI, imunomodulator (Estiasih et al., 2013), penurunan kolesterol (Estiasih et al., 2014), dan antioksidan (Estiasih, 2014).

\section{Karakteristik mikroemulsi}

Fraksi tidak tersabunkan yang mengandung senyawa tokoferol, tokotrienol, fitosterol, dan skualen, digunakan sebagai fase terdispersi dalam pembuatan mikroemulsi.

Tabel 2. Kadar senyawa bioaktif dalam DALMS dan FTT

\begin{tabular}{|c|c|c|c|c|c|c|}
\hline \multirow{2}{*}{ Senyawa Bioaktif } & \multicolumn{2}{|c|}{ DALMS } & \multicolumn{2}{|l|}{ FTT } & \multicolumn{2}{|c|}{ Mikroemulsi } \\
\hline & ppm & $\%$ & ppm & $\%$ & ppm & $\%$ \\
\hline Vitamin E & $47,682 \pm 517$ & 4,77 & $342,375 \pm 6,095$ & 34,24 & $714 \pm 48$ & 0,071 \\
\hline a tokoferol & $775 \pm 86$ & 0,08 & $7,493 \pm 234$ & 0,75 & $2 \pm 0,77$ & 0,002 \\
\hline$\alpha$ tokotrienol & $10,796 \pm 101$ & 1,08 & $166,700 \pm 4,576$ & 16,67 & $134 \pm 9$ & 0,013 \\
\hline$\delta$ tokotrienol & $1,908 \pm 98$ & 0,19 & $32,121 \pm 287$ & 3,21 & $252 \pm 1$ & 0,025 \\
\hline y tokotrienol & $34,201 \pm 232$ & 3,42 & $136,060 \pm 998$ & 13,61 & $325 \pm 24$ & 0,033 \\
\hline Total tokotrienol & $46,906 \pm 431$ & 4,69 & $334,882 \pm 5,861$ & 33,49 & $712 \pm 47$ & 0,071 \\
\hline Fitosterol & $64,64 \pm 229$ & 0,65 & $154,757 \pm 1,175$ & 15,48 & $832 \pm 39$ & 0,083 \\
\hline Beta sitosterol & $1,952 \pm 67$ & 0,20 & $78,506 \pm 456$ & 7,85 & $80 \pm 6$ & 0,008 \\
\hline Stigmasterol & $1,515 \pm 28$ & 0,15 & $5,254 \pm 65$ & 0,53 & $41 \pm 2$ & 0,004 \\
\hline Kampesterol & $2,997 \pm 134$ & 0,30 & $70,996 \pm 654$ & 7,10 & $711 \pm 31$ & 0,071 \\
\hline Skualen & $1,410 \pm 347$ & 0,14 & $2,101 \pm 487$ & 2,10 & $25 \pm 1$ & 0,003 \\
\hline
\end{tabular}


Metode yang digunakan dalam pembuatan mikroemulsi adalah metode dengan proses mekanik, yaitu homogenisasi menggunakan ultraturax dengan kecepatan $12.000 \mathrm{rpm}$ selama 20 menit.

\section{Viskositas mikroemulsi}

Pengaruh penggunaan jenis dan konsentrasi pengemulsi terhadap viskositas mikroemulsi dapat dilihat pada Gambar 1A. Jenis dan konsentrasi pengemulsi tidak memberikan pengaruh nyata terhadap viskositas. Ada kecenderungan bahwa semakin tinggi konsentrasi pengemulsi, maka viskositas semakin meningkat. Hal ini disebabkan fase padatan dalam sistem emulsi semakin meningkat. Fase padatan yang tinggi dapat mempengaruhi viskositas mikroemulsi. Pengemulsi merupakan molekul amfifilik yang berpartisi pada fase terdispersi dan pendispersi. Pada konsentrasi pengemulsi yang tinggi, pengemulsi dapat membentuk misel (Mozrzymas dan Rozycka-Roszak, 2010) yang berkontribusi terhadap peningkatan viskositas sistem emulsi. Konsentrasi misel kritis juga dipengaruhi oleh fraksi volume minyak. Semakin tinggi pengemulsi, kemungkinan pembentukkan misel semakin tinggi sehingga viskositas sistem emulsi meningkat. Kemungkinan pembentukkan misel pada lesitin lebih mudah dibandingkan tween 80. Menurut Widjajanti dan Tutik (2004), konsentrasi misel kritis untuk lesitin adalah $(3,62 \mathrm{X}$ $10^{-4} \%$ ) pada kondisi tanpa fase terdispersi dan kecepatan agitasi $400 \mathrm{rpm}$ selama 15 menit. Fraksi minyak meningkatkan konsentrasi misel kritis karena lesitin bermigrasi pada antar muka droplet emulsi untuk stabilisasi. Menurut Mahmood dan Koofee (2013) konsentrasi misel kritis tween 80 adalah $0,0015 \mathrm{mM}$.

Viskositas sistem emulsi yang distabilkan oleh lesitin cenderung lebih tinggi dibandingkan tween 80. Perbedaan ini diduga disebabkan oleh perbedaan struktur molekul keduanya. Lesitin merupakan nama komersial dari fosfatidilkolin (Cheng et al., 2014). Bagian hidrofobik lesitin merupakan dua rantai asam lemak yang jenisnya bergantung pada sumber lesitin (Bueschelberger, 2004). Asam lemak dalam kedelai didominasi oleh asam lemak rantai panjang seperti linoleat (Wang dan Wang, 2008). Tween 80 atau nama lainnya polysorbate 80 adalah pengemulsi dengan gugus hidrofilik berupa polioksietilen sorbitan dan gugus hidrofobik berupa oleat (Mahmood dan Koofee, 2013). Perbedaan jumlah asam lemak pada pengemulsi diduga berpengaruh terhadap viskositas sistem emulsi. Menurut Cheng et al. (2014), fosfolipid dapat membentuk gel atau fluida viskoelastis di dalam air.

\section{Stabilitas mikroemulsi terhadap pemisahan}

Jenis dan konsentrasi pengemulsi tidak memberikan pengaruh nyata terhadap indeks turbiditas mikroemulsi. Pengukuran stabilitas terhadap pemisahan ini dilakukan setelah 7 hari penyimpanan pada suhu $30^{\circ} \mathrm{C}$. Indikator pemisahan fase antara lain adalah peningkatan kekeruhan yang dinyatakan dengan indeks turbiditas. Mikroemulsi dianggap stabil jika nilai turbiditas kurang dari $1 \%$ (Cho et al., 2008). Mikroemulsi memiliki rerata turbiditas di atas $1 \%$, ini menunjukkan bahwa mikroemulsi bersifat tidak stabil.

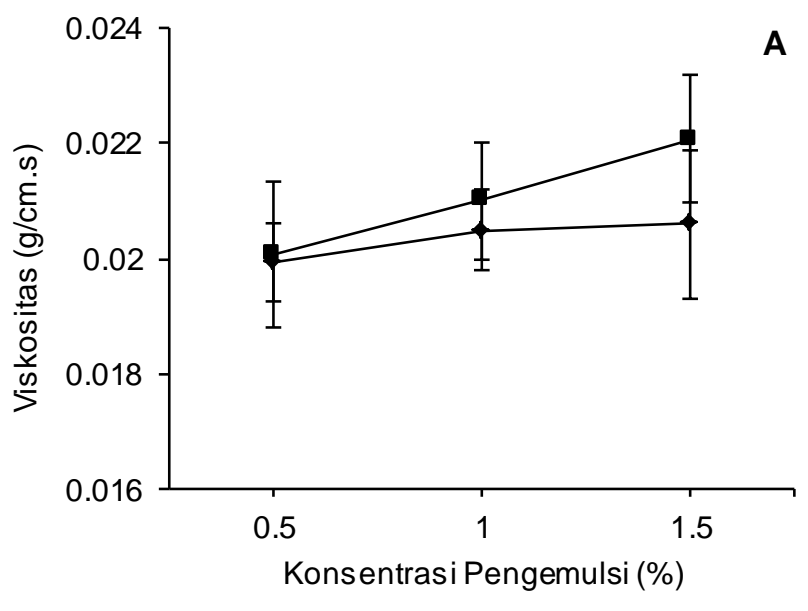

$\longrightarrow$ Mikroemulsi Lesitin $\rightarrow$ Mikroemulsi Tween 80

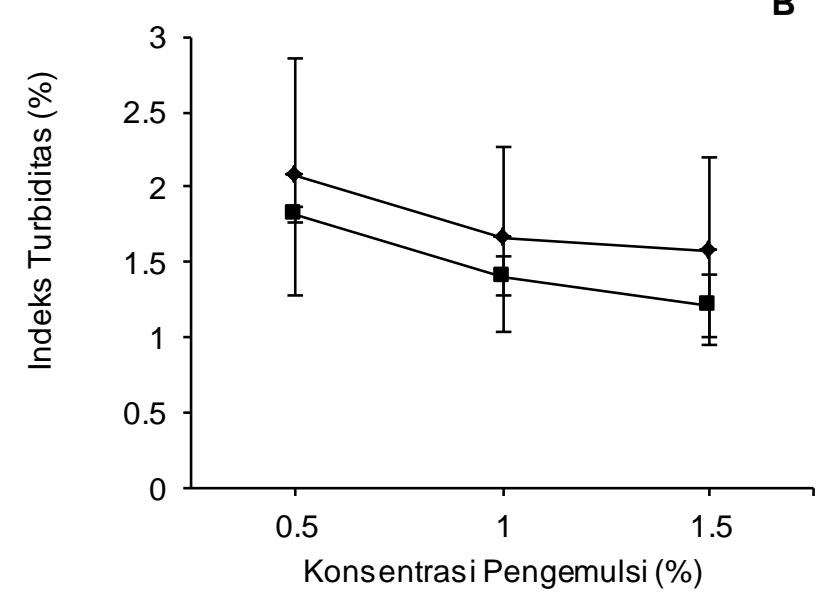

$\longrightarrow$ Mikroemulsi Lesitin $\rightarrow$ Mikroemulsi Tween 80

Gambar 1. Viskositas (A) dan stabillitas (indeks turbiditas) (B) mikroemulsi pada berbagai jenis dan konsentrasi pengemulsi

Menurut Shen et al. (2005), stabilitas emulsi dipengaruhi oleh jenis surfaktan. Gambar 1B menunjukkan bahwa emulsi yang distabilisasi menggunakan tween 80 cenderung lebih stabil dibandingkan lesitin, walaupun perlakuan jenis dan konsentrasi pengemulsi tidak menunjukkan pengaruh yang nyata terhadap stabilitas emulsi. Perbedaan kecenderungan tersebut diduga disebabkan perbedaan nilai HLB dari kedua pengemulsi tersebut. Nilai HLB tween 80 adalah 15 sedangkan nilai HLB lesitin 
adalah 4 (Estiasih et al., 2013). Menurut Bueschelberger (2004), HLB pengemulsi 2-6 mempunyai kelarutan yang rendah dalam air dan digunakan untuk menstabilkan emulsi minyak dalam air. HLB untuk lesitin biasanya antara 2-7, tetapi karena bersifat ionik, kategori sifat pengemulsi berdasarkan HLB untuk lesitin menjadi tidak berlaku. Walaupun demikian, dari hasil penelitian ini terlihat bahwa tween 80 lebih mampu menstabilkan emulsi FTT. Ada kesesuaian jenis globula atau droplet fase terdispersi dengan jenis pengemulsi. Menurut Hasenhuetti (2008) pengemulsi dengan asam lemak jenuh sesuai untuk menstabilkan lemak yang juga jenuh. FTT merupakan kumpulan senyawa tidak tersabunkan yang bersifat hidrofobik yang mengandung vitamin E, fitosterol, dan skualen. Pada suhu ruang, FTT bersifat semi padat sehingga pengemulsi yang sesuai adalah pengemulsi yang juga padat pada suhu ruang atau lebih jenuh. Hal ini yang menyebabkan tween 80 lebih mampu menstabilkan emulsi FTT karena mengandung asam lemak yaitu oleat yang lebih jenuh dari asam lemak dominan pada lesitin, yaitu linoleat.

Peningkatan konsentrasi pengemulsi menyebabkan peningkatan kestabilan emulsi. Hal ini disebabkan oleh ketersediaan pengemulsi yang meningkat sehingga jumlahnya cukup untuk menstabilkan permukaan droplet emulsi. Permukaan globula yang tersalut dengan baik oleh pengemulsi akan menghambat proses destabilisasi yang diawali dengan flokulasi, dilanjutkan dengan koalesensi dan pemisahan fase. Indeks turbiditas yang diukur menunjukkan destabilisasi emulsi karena emulsi yang mengalami koalesensi akan mempunyai luas permukaan droplet yang lebih rendah sehingga kenampakan emulsi akan lebih keruh akibat efek Tyndall atau penghabluran cahaya yang lebih rendah.

\section{Distribusi ukuran partikel mikroemulsi}

Ukuran partikel mempengaruhi berbagai produk yang mengandung partikulat dan merupakan salah satu indikator mutu dan performa produk. Dalam sistem emulsi, semakin kecil ukuran droplet menyebabkan emulsi semakin stabil (McClements, 2015). Pada penelitian ini distribusi ukuran partikel ditunjukkan oleh nilai D10, D50, dan D90. Nilai D10 menunjukkan bahwa terdapat $10 \%$ partikel droplet memiliki ukuran lebih kecil daripada ukuran droplet D10. Demikian pula untuk D50 dan D90 yang menunjukkan bahwa terdapat 50 dan $90 \%$ droplet berukuran lebih kecil daripada ukuran diameter D50 dan D90. D50 juga menunjukkan median dari ukuran partikel droplet emulsi. Lebar interval distribusi partikel biasa dinyatakan sebagai (D90D10)/D50 (Cilas, 2004).

Gambar 2 menunjukkan distribusi ukuran partikel mikroemulsi pada masing-masing sampel hanya terdapat satu puncak. Hal ini berarti bahwa distribusi ukuran partikel bersifat monomodal sebagai penanda bahwa emulsi cukup stabil.

Menurut Marquez dan Wagner (2012), distribusi ukuran droplet emulsi yang tidak stabil ditunjukkan oleh hasil pengamatan berupa banyak puncak (multimodal). Destabilisasi emulsi dengan distribusi multimodal disebabkan oleh kelompok ukuran droplet emulsi yang sangat beragam. Perbedaan ukuran ini cenderung menyebabkan gaya tarik antar droplet menjadi tinggi sehingga emulsi cenderung mengalami Ostwald ripening sebagai awal dari destabilisasi (Tadros, 2013). Faktor penting yang mempengaruhi stabilitas emulsi adalah ukuran droplet. Pada penelitian ini rata-rata diameter droplet dapat dilihat pada Tabel 3. Droplet emulsi yang kecil menunjukkan emulsi semakin stabil (Ogawa et al., 2004). Menurut Kobayashi et al. (2005), gerak droplet dalam emulsi terutama ditentukan oleh kesetimbangan antara gaya gravitasi dan gerak Brown. Gravitasi menyebabkan sedimentasi droplet, sedangkan gerak Brown mendistribusikan secara acak droplet dalam sistem emulsi. Gerak Brown lebih dominan untuk droplet emulsi yang berukuran kecil sehingga dapat mencegah fenomena sedimentasi.

Ukuran droplet dalam emulsi ditentukan oleh dua proses kompetitif yaitu pemecahan droplet dan koalesensi (Henry et al., 2010). Tabel 3 menunjukkan bahwa rerata ukuran droplet emulsi dipengaruhi oleh jenis pengemulsi. Ukuran droplet yang lebih besar terdapat pada emulsi yang distabilkan oleh lesitin. Qian et al. (2011) menyatakan bahwa jenis pengemulsi mempengaruhi ukuran droplet dalam emulsi. Ukuran droplet emulsi yang distabilkan oleh lesitin cenderung lebih besar dibandingkan emulsi yang distabilkan oleh tween 80 . Artinya tween 80 lebih baik dalam menstabilkan emulsi FTT. Perbedaan HLB dan struktur molekul keduanya diduga mempengaruhi kemampuan stabilisasi. HLB tinggi sesuai untuk sistem emulsi o/w sedangkan HLB rendah untuk emulsi w/o, walaupun penggunaan HLB untuk lesitin tidak sepenuhnya sesuai akibat lesitin merupakan pengemulsi ionik (Bueschelberger, 2004).

Peningkatan konsentrasi lesitin menyebabkan rerata diameter droplet semakin menurun, tetapi hal sebaliknya terjadi untuk tween 80 . Penurunan diameter droplet emulsi yang distabilkan oleh lesitin akibat peningkatan konsentrasi lesitin disebabkan ketersediaan lesitin untuk menstabilkan droplet emulsi semakin banyak. Akibatnya luas permukaan droplet yang dapat ditutupi lesitin semakin tinggi pada kondisi homogenisasi yang sama. Henry et al. (2010) menjelaskan bahwa fosfolipid pada konsentrasi tinggi tidak menyebabkan peningkatan ukuran droplet tetapi pada konsentrasi rendah dapat terjadi koalesensi. 

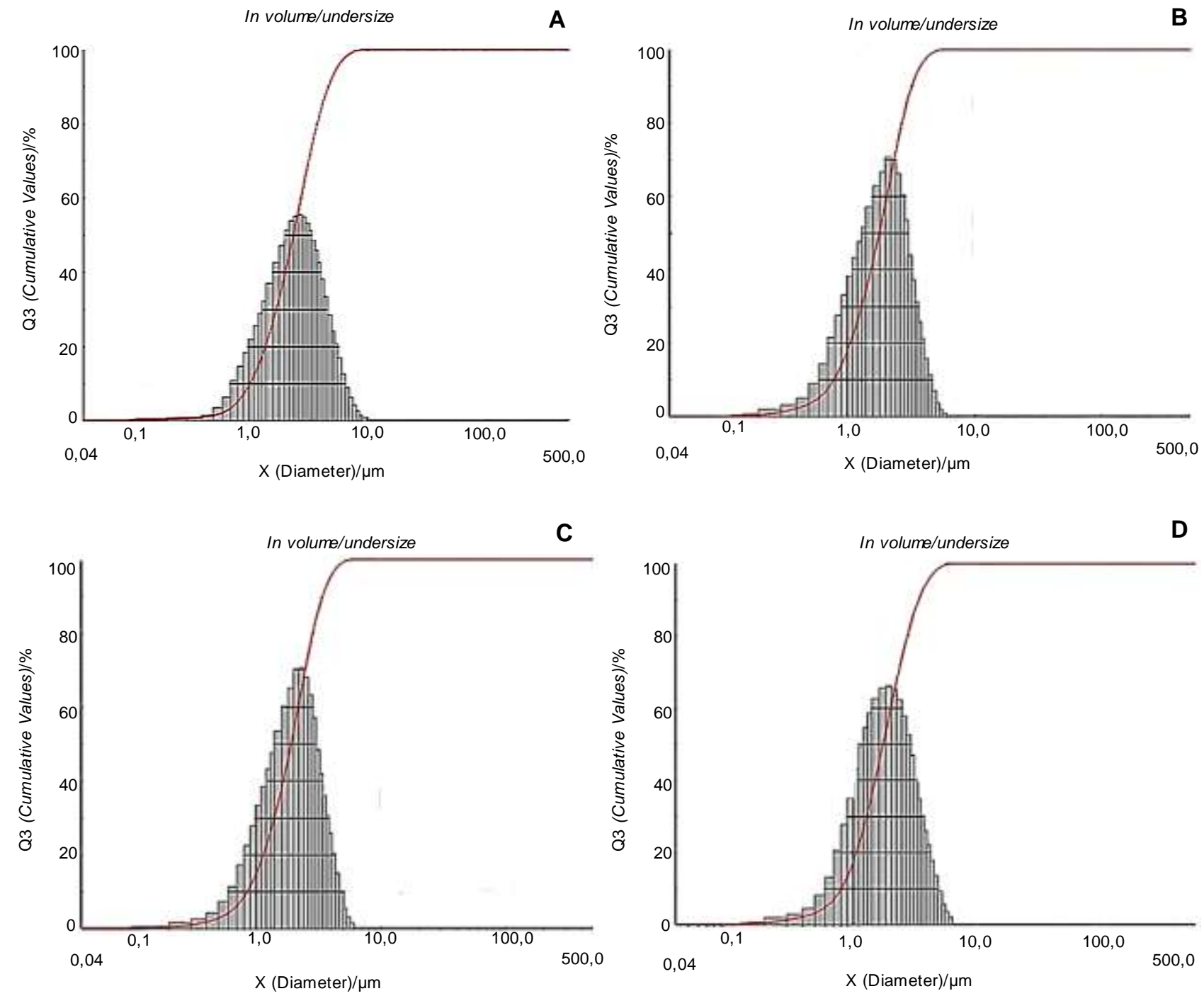

$\mathbf{E}$
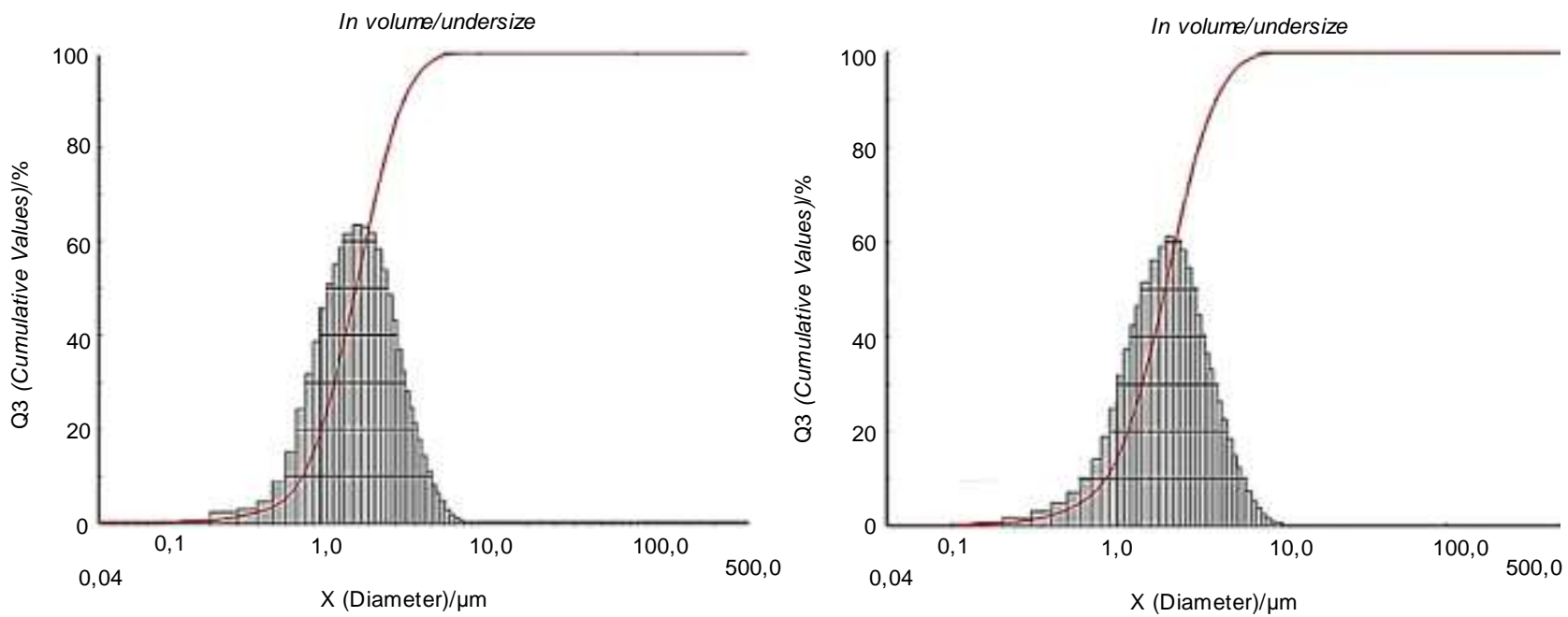

Gambar 2. Distribusi ukuran partikel mikroemulsi dengan pengemulsi lesitin $0,5 \%(A), 1,0 \%(B)$, dan $1,5 \%$ (C) serta tween $800,5 \%(D), 1,0 \%(E)$, dan $1,5 \%(F)$ 
Pada sistem emulsi yang distabilkan oleh tween 80 peningkatan konsentrasi tween 80 menyebabkan rerata ukuran droplet semakin meningkat. Lesitin merupakan pengemulsi ionik yang pada permukaan globula lemak akan berkontribusi memberikan muatan (Bueschelberger, 2004). Muatan ini menyebabkan gaya tolak (repulsion forces) yang turut berperan meningkatkan stabilitas emulsi (Tadros, 2013). Hasil penelitian Yuan et al. (2008) menunjukkan peningkatan konsentrasi berbagai jenis pengemulsi tween menyebabkan penurunan ukuran partikel pada kondisi homogenisasi yang sama. Ukuran partikel yang lebih kecil mempunyai luas permukaan yang lebih besar yang membutuhkan pengemulsi yang lebih banyak. Pada tween 80 , penurunan ukuran droplet emulsi tidak terjadi lagi pada konsentrasi lebih dari $6 \%$ karena semua permukaan telah terselubungi pengemulsi dan penambahan pengemulsi lebih lanjut tidak akan digunakan untuk menstabilkan permukaan droplet.

Gambar 2 dan Tabel 3 menunjukkan bahwa semakin tinggi konsentrasi lesitin menyebabkan rentang ukuran partikel droplet emulsi semakin sempit yang berarti emulsi semakin stabil, akan tetapi fenomena sebaliknya terjadi untuk sistem emulsi yang distabilisasi tween 80. Ukuran droplet yang tidak seragam cenderung menyebabkan flokulasi sebagai tahap awal ketidakstabilan. Flokulasi cenderung terjadi antar droplet yang berukuran tidak seragam. Droplet berukuran kecil biasanya menempel pada droplet berukuran besar. Dengan demikian, ukuran droplet yang seragam yang ditunjukkan rentang distribusi ukuran yang makin sempit menyebabkan disparitas ukuran droplet menjadi kecil, mengindikasikan emulsi menjadi lebih stabil. Menurut McClements (2015) stabilitas emulsi dipengaruhi oleh distribusi droplet emulsi, yaitu emulsi lebih stabil jika droplet berukuran seragam. Ukuran droplet yang seragam menyebabkan kemungkinan flokulasi antar droplet menjadi lebih rendah. Hasil penelitian Lu et al. (2012) menunjukkan bahwa semakin tinggi konsentrasi fosfolipid menyebabkan emulsi semakin tidak stabil. Hal ini disebabkan fosfolipid yang berlebihan dapat menstimulasi pembentukkan liposom dengan air yang dapat terbentuk pada saat homogenisasi. Pada penelitian tersebut konsentrasi fosfolipid yang digunakan adalah 0,5-10\%. Henry et al. (2010) sebelumnya menjelaskan bahwa fosfolipid alami lebih sesuai untuk menstabilkan emulsi w/o dibandingkan o/w karena nilai HLB yang dimilikinya rendah. Untuk meningkatkan pengguna lesitin terutama untuk sistem emulsi o/w, lesitin biasanya dimodifikasi dengan berbagai cara seperti hidrolisis parsial, atau penambahan gugus lain yang lebih hidrofilik.

\section{Mikrostruktur mikroemulsi}

Pengamatan mikrostruktur mikroemulsi menggunakan SEM ditujukan untuk melihat kemungkinan adanya destabilisasi yang diindikasikan dengan flokulasi atau koalesensi. Emulsi FTT yang distabilkan dengan lesitin atau tween 80 menunjukkan ukuran droplet yang beragam sesuai dengan hasil analisis particle size analyzer. Sebagian besar droplet berbentuk bulat, dan sebagian kecil bergerombol. Yuan et al. (2008) melaporkan bahwa droplet $\beta$-karoten dalam sistem nanoemulsi berbentuk bulat atau batang pendek, dan sebagian berbentuk batang atau tidak beraturan yang disebabkan aglomerasi partikel kecil.

Gambar 3 menunjukkan bahwa emulsi yang distabilkan dengan lesitin mempunyai bentuk droplet yang tidak beraturan dan sebagian bergerombol yang mengindikasikan terjadi flokulasi (Gambar 3A) dan koalesensi (Gambar 3C). Emulsi yang distabilkan lesitin pada konsentrasi 0,5 dan 1,5\% menunjukkan droplet emulsi yang lebih tidak beraturan dibandingkan lesitin 1,0\%. Data ini sejalan dengan hasil analisis ukuran pertikel yang menunjukkan ukuran droplet emulsi yang paling kecil terdapat pada emulsi yang distabilkan dengan konsentrasi $1,0 \%$. Pada konsentrasi lesitin rendah, lesitin tidak cukup banyak untuk menstabilkan permukaan droplet emulsi.

Menurut Tan dan Nakajima (2005), ketidakcukupan pengemulsi dalam menyelubungi permukaan droplet dapat menyebabkan koalesensi. Mikroemulsi yang distabilkan dengan tween 80 menunjukkan bentuk droplet emulsi yang lebih beraturan dan berbentuk bulat. Ukuran droplet terkecil terlihat pada mikroemulsi yang distabilkan dengan tween 80 pada konsentrasi $0,5 \%$.

Tabel 3. Distribusi ukuran partikel mikroemulsi

\begin{tabular}{lcccccc}
\hline Pengemulsi & Konsentrasi $(\%)$ & $\begin{array}{c}\text { D10 } \\
(\mu \mathrm{m})\end{array}$ & $\begin{array}{c}\text { D50 } \\
(\mu \mathrm{m})\end{array}$ & $\begin{array}{c}\text { D90 } \\
(\mu \mathrm{m})\end{array}$ & Distribusi Ukuran* & Rerata Diameter $(\mu \mathrm{m})$ \\
\hline Lesitin & 0,5 & $1,01 \pm 0,02$ & $2,37 \pm 0,06$ & $4,70 \pm 0,11$ & $1,56 \pm 0,02$ & $3,04 \pm 0,10$ \\
& 1,0 & $0,78 \pm 0,00$ & $1,79 \pm 0,05$ & $3,21 \pm 0,09$ & $1,36 \pm 0,02$ & $2,23 \pm 0,06$ \\
Tween 80 & 1,5 & $0,84 \pm 0,01$ & $1,90 \pm 0,04$ & $3,40 \pm 0,10$ & $1,35 \pm 0,03$ & $2,36 \pm 0,05$ \\
& 0,5 & $0,80 \pm 0,00$ & $1,71 \pm 0,03$ & $3,27 \pm 0,08$ & $1,44 \pm 0,03$ & $2,22 \pm 0,06$ \\
& 1,0 & $0,77 \pm 0,02$ & $1,67 \pm 0,03$ & $3,34 \pm 0,07$ & $1,54 \pm 0,02$ & $2,24 \pm 0,05$ \\
& 1,5 & $0,85 \pm 0,01$ & $1,96 \pm 0,05$ & $3,99 \pm 0,11$ & $1,60 \pm 0,02$ & $2,62 \pm 0,04$ \\
\hline
\end{tabular}

Keterangan: *Dihitung dari (D90-D10)/D50 
Hal ini sejalan dengan analisis ukuran partikel yang menunjukkan rerata ukuran droplet terkecil terdapat pada konsentrasi tween 80. Pada sistem mikroemulsi ini tidak teramati flokulasi atau koalesensi. Hal ini menunjukkan bahwa mikroemulsi yang distabilkan tween 80 mempunyai performa yang lebih baik dibandingkan lesitin.

\section{Senyawa bioaktif mikroemulsi}

Keuntungan menggunakan mikroemulsi adalah ketersediaan dan efisiensi biologis dari senyawa bioaktif lipofilik yang lebih tinggi dibandingkan menggunakan sistem emulsi biasa. Mikroemulsi memiliki luas permukaan yang lebih besar sehingga lebih efektif sebagai sistem pembawa senyawa bioaktif. Selain itu, mikroemulsi FTT lebih mudah ditangani dibandingkan FTT yang berupa pasta kental. Menurut McClements et al. (2015) bioavailabilitas senyawa bioaktif dibatasi oleh sifat fisikokimia dan fisiologis dalam saluran pencernaan. Bioavailabilitas ini dipengaruhi oleh keterbatasan pelepasan, metabolisme atau perubahan selama melewati saluran pencernaan, kelarutan yang rendah dalam cairan usus, dan permeasi yang rendah. Oleh karena itu, senyawa bioaktif seringkali diubah strukturnya untuk meningkatkan bioavailabilitasnya, seperti emulsi.
Kadar senyawa bioaktif yang terdapat dalam mikroemulsi dapat dilihat pada Tabel 1. Mikroemulsi mempunyai kadar senyawa bioakif yang jauh lebih rendah dari FTT dan DALMS. Penelitian-penelitian sebelumnya melaporkan bahwa penggunan homogenizer bertekanan tinggi selama persiapan nanodispersi dapat menurunkan kadar komponen fungsional (Tan dan Nakajima, 2005; Cheong et al., 2008; Leong et al., 2011). Selain kemungkinan terjadi kerusakan selama pembuatan mikroemulsi, penurunan kadar senyawa bioaktif juga disebabkan oleh proses pengenceran karena kadar FTT yang digunakan dalam sistem mikroemulsi adalah $10 \%$.

Secara teoritis seharusnya kadar senyawa bioakif dalam mikroemulsi adalah $10 \%$ dari kadarnya di dalam FTT. Penurunan yang tajam dapat disebabkan oleh kerusakan akibat panas selama proses emulsifikasi akibat gaya gesekan yang tinggi, atau juga senyawa bioaktif teroksidasi akibat inkorporasi udara ke dalam sistem emulsi selama kavitasi. Anarjan et al. (2014) menduga bahwa kerusakan astaxanthin selama homogenisasi pada pembuatan nanodispersi disebabkan oleh peningkatan luas permukaan droplet emulsi dan pembentukkan radikal bebas.
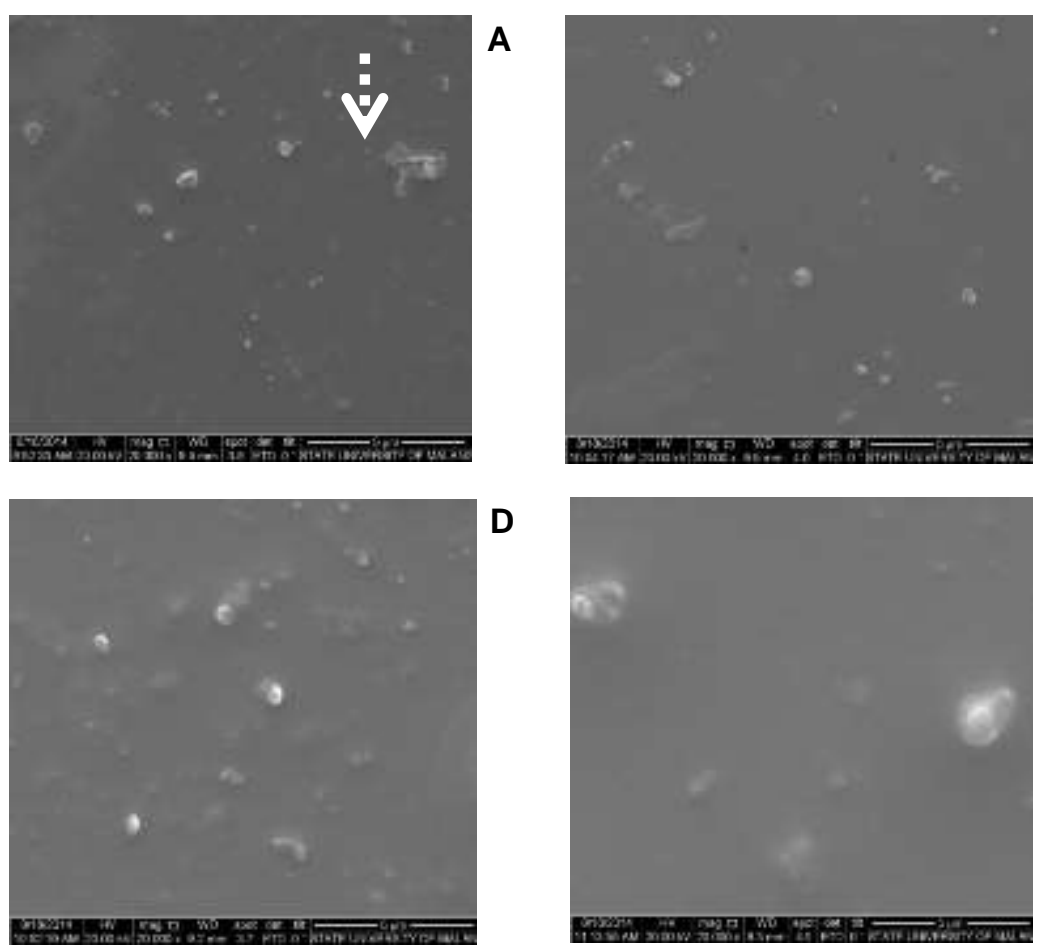
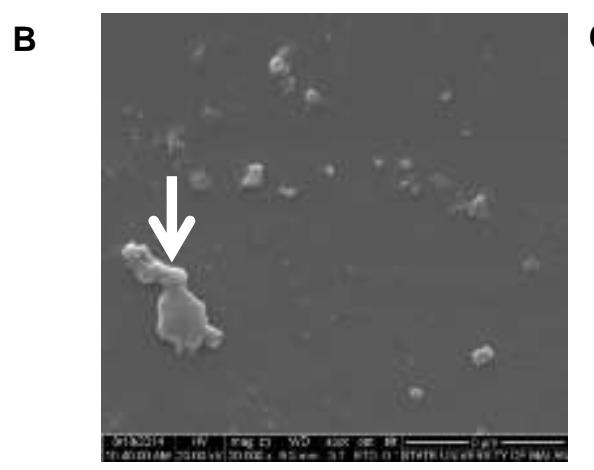

C

E

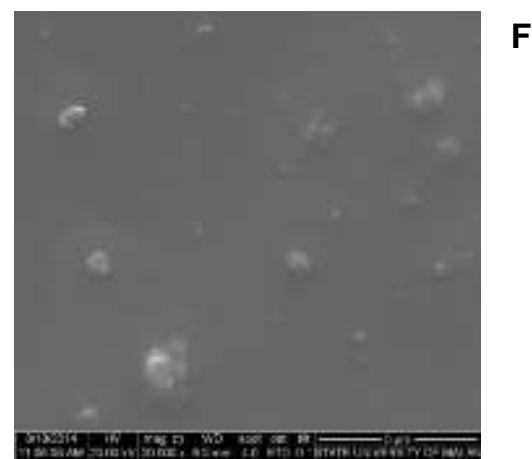

Gambar 3. Mikrostruktur mikroemulsi dengan pengemulsi lesitin 0,5\% (A), 1,0\% (B), 1,5\% (C) dan tween 80 $0,5 \%(D), 1,0 \%(E)$, dan $1,5 \%(F)$ (perbesaran 20.000 kali). $\longrightarrow$ koalesensi,- $-\rightarrow$ flokulasi 


\section{KESIMPULAN}

FTT dapat dibuat emulsi dengan menggunakan homogenisasi pada kecepatan 12.000 rpm selama 20 menit. Emulsi yang dihasilkan mempunyai kisaran ukuran droplet kurang dari $10 \mu \mathrm{m}$ yang dapat dikategorikan sebagai mikroemulsi. Lesitin dan tween 80 dapat menstabilkan mikroemulsi FTT dan performa mikroemulsi dipengaruhi jenis pengemulsi dan konsentrasinya. Tween 80 menghasilkan emulsi yang lebih baik dibandingkan lesitin yang diindikasikan oleh ukuran droplet yang lebih kecil, rentang distribusi ukuran partikel yang lebih sempit, dan mikroemulsi yang lebih stabil. Peningkatan konsentrasi lesitin menghasilkan mikroemulsi dengan distribusi ukuran droplet yang lebih sempit, sedangkan rata-rata ukuran droplet tidak selalu lebih kecil. Sebaliknya, peningkatan konsentrasi tween 80 menyebabkan rata-rata ukuran droplet dan interval distribusi ukuran droplet yang lebih besar. Pengemulsi yang sesuai untuk mikroemulsi FTT adalah tween 80 dengan konsentrasi $0,5 \%$. Mikroemulsi ini mengandung senyawa bioaktif berupa vitamin E (terutama tokotrienol), fitosterol, dan skualen, tetapi kadarnya sangat rendah, yaitu vitamin E 714 ppm, fitosterol 832 ppm, dan skualen 25 ppm.

\section{UCAPAN TERIMAKASIH}

Ucapan terima kasih yang sebesar-besarnya disampaikan kepada Direktorat Jenderal Pendidikan Tinggi Kementerian Pendidikan dan Kebudayaan atas pendanaan penelitian ini melalui Hibah Penelitian MP3EI Tahun 2014.

\section{DAFTAR PUSTAKA}

Anarjan N, Nehdi IA, Sbihi HM, Al-Resayes SI, Malmiri HJ, Tan CP. 2014. Preparation of astaxanthin nanodispersions using gelatinbased stabilizer systems. Molecule 19: 1425714265. DOI: 10.3390/molecules 190914257.

[AOCS] American Oil Chemist Society. 1990. Official Methods and Recommended Practices of the American Oil Chemistry Society. 4th ed., Broadmaker Drive, Champaign, Illinois.

Benites $\mathrm{Cl}$, Chonca VOC, Reis SMPM, De Oliveirra OC. 2009. Physiochemical characterization of soybean oil deodorizer distillate. Chem Eng Trans J 17: 903-908. DOI: 10.3303/CET09171 51.

Bueschelberger HG. 2004. Lecithins. In Whitehurst RJ (ed.). Emulsifiers in Food Technology. 1-39. Blackwell Publishing Ltd, Oxford.
Cabezas DM, Diehl BWK, Tomás MC. 2009. Sunflower lecithin: application of a fractionation process with absolute ethanol. J Am Oil Chem Soc 86: 189-196. DOI 10.1007/s11746-00813 36-5.

Cabezas DM, Madoery R, Diehl BWK, Tomas, MC. 2012. Emulsifying properties of different modified sunflower lecithins. J Am Oil Chem Soc 89: 355-361. DOI 10.1007/s11746-011191 5-8.

Cheng CY, Oh $\mathrm{H}$, Wang TY, Raghavan SR, Tung $\mathrm{SH}$. 2014. Mixtures of lecithin and bile salt can form highly viscous wormlike micellar solutions in water. Langmuir 30: 10221-10230. DOI: 10.1021/la502380q.

Cheong JN, Tan CP, Man YBC, Misran M. 2008. Tocopherol nanodispersions: preparation, characterization and stability evaluation. J Food Eng 89: 204-209. DOI: 10.1016/j.jfoodeng. 2008.04.018.

Cho YH, Kim S, Bae EK, Mok CK, Park J. 2008. Formulation of a cosurfactant-free o/w microemulsion using nonionic surfactant mixtures. J Food Sci 73: 115-121. DOI: 10.1111/j.17503841.2008.00688.x.

Cilas. 2004. Particle size analyzer cilas 920,930e,1064 \& 1180 user Manual. www. particle-size-analyzer.com. [28 Oktober 2015].

Estiasih T, Ahmadi K, Widyaningsih TD, Maligan JM. 2013. Senyawa Bioaktif Multikomponen dari Distilat Asam Lemak Minyak Sawit untuk Meningkatkan Nilai Tambah Industri Pengolahan Minyak Goreng. Laporan Penelitian MP3EI Tahun 2, Universitas Brawijaya, Malang.

Estiasih T, Ahmadi K, Widyaningsih TD, Rhitmayanti E, Fidyasari S, Purnomo K, Wahyuni Y. 2014. The effect of unsaponifiable fraction from palm fatty acid distillate on lipid profile of hypercholesterolaemia rats. J Food Nutr Res 2: 1029-1036. DOI: 10.12691/jfnr-2-12-26.

Estiasih T. 2014. Antioxidant Activity of Unsaponifiable Fraction of Palm Fatty Acid Distillate on Peroxidation Rats. 10th Young Scientist Seminar, Nov 16-17, Yamaguchi, Jepang.

Gapoor A, Hassan WHW, Sulong M. 2002. Phytochemical for nutraceutical from the by product of palm oil refining. Palm Oil Develop 36: 13-19.

Hasenhuetti GL. 2008. Synthesis and Commercial Preparation of Food Emulsifiers. In Hasenhuettl GL, Hartel RW (eds). Food Emulsifiers and Their Applications. 11-30. Springer Science+Business Media LLC, New York.

Henry JVL, Fryer PJ, Frith WJ, Norton IT. 2010. The influence of phospholipids and food proteins on the size and stability of model sub-micron 
emulsions. Food Hydrocolloid 24: 66-71. DOI: 10.1016/j.foodhyd.2009.08.006.

Imai H, Maeda T, Shima M, Adachi S. 2008. Oxidation of methyl linoleate in oil-in-water micro- and nanoemulsion systems. J Am Oil Chem Soc 85: 809-815. DOI 10.1007/s11746008-1257-3.

[IUPAC] International Union of Pure and Applied Chemistry. 1979. Standards Methods for the Analysis of Oils and Fats Derivatives 6th edn. Pergamon Press, Oxford, (U.K).

Khatoon S, Raja RGR, Krishna AGG. 2010. Physicochemical characteristics and composition of Indian soybean oil deodorizer distillate and the recovery of phytosterols. J Am Oil Chem Soc 87: 321-326. DOI: 10.1007/s111746009-1499-8.

Kim OS. 2005. Radical scavenging capacity and antioxidant activity of the $E$ vitamer fraction in rice bran. J Food Sci 70: 208-213. DOI: 10.1111/j.1365-2621.2005.tb07127.x.

Kobayashi I, Lou X, Mukataka S, Mitsutoshi N. 2005. Preparation of monodisperse water-in-oil-inwater emulsions using microfluidization and straight-through microchannel emulsification. J Am Oil Chem Soc 82: 65-71. DOI: 10.1007/ s11746-005-1044-y.

Leong WF, Cheong KW, Lai OM, Long K, Man YBC, Misran M, Tan CP. 2011. Response surface modeling of processing parameters for the preparation of phytosterol nanodispersions using an emulsification-evaporation technique. $J$ Am Oil Chem Soc 88: 717-725. DOI: 10.1007/s11746-010-1714-7.

Loganathan R, Selvaduray KR, Radhakrishnan A, Nesaretnam K. 2009. Palm oil rich in health promoting phytonutrients. Palm Oil Develop 50: 16-25.

Lu FSH, Nielsen NS, Baron CP, Jensen LHS, Jacobsen C. 2012. Physico-chemical properties of marine phospholipid emulsions. J Am Oil Chem Soc 89: 2011-2024. DOI 10.1007/ s11746-012-2105-z.

Mahmood ME, Koofee DAF. 2013. Effect of temperature changes on critical micelle concentration for tween series surfactant. Glob $\mathrm{J}$ Sci Frontier Res Chem 13: 1-8.

Majoni S, Wang T. 2010. Characterization of oil precipitate and oil extracted from condensed corn distiller solubles. J Am Oil Chem Soc 87: 205-213. DOI: 10.1007/s11746-009-1491-3.

Madaan V, Chanana K, Kataria MK, Bilandi A. 2014. Emulsion technology and recent trends in emulsion application. Int Res J Pharm 5: 533542. DOI: $10.7897 / 2230-8407.0507108$.
Marquez AL, Wagner JR. 2012. Rheology of creamlike emulsions prepared with soybean milk and low trans vegetable fat. J Am Oil Chem Soc 89: 1857-1865. DOI 10.1007/s11746-012-2093-z.

McClements DJ. 2015. Food Emulsions: Principles, Practices, and Techniques. $3^{\text {rd }}$ Ed. 11-27, 134166. CRC Press, Boca Raton, Florida.

McClements DJ, Zou L, Zhang R, Salvia-Trujillo L, Kumosani T, Xao H. 2015. Enhancing nutraceutical performance using excipient foods: designing food structures and compositions to increase bioavailability. Compr Rev Food Sci $F$ 14: 824-847. DOI: 10.1111/1541-4337. 12170.

Mendez E, Blanco M, Laguna A, Garcia E. 2003. Isolation and characterization of a mixture of higher primary aliphatic alcohols of high molecular weight from henequen (Agave furcroydes L.) wax. Revista CENIC Ciencias Químicas 34: 35-38.

Mozrzymas A, Rozycka-Roszak B. 2010. Prediction of critical micelle concentration of nonionic surfactants by quantitative structure property relationship. Comb Chem High Screen 13: 3944.

Naz S, Sherazi STH, Talpur FN, Kara K, Uddin S, Khaskheli AR. 2014. Chemical characterization of canola and sunflower oil deodorizer distillates. Pol J Food Nutr Sci 64: 115-120. DOI: 10.2478/pjfns-2013-0008.

Nik AM, Wright AJ, Corredig M. 2011. Micellization of beta-carotene from soy-protein stabilized oilin-water emulsions under in vitro conditions of lipolysis. J Am Oil Chem Soc 88: 1397-1407. DOI: $10.1007 / \mathrm{s} 11746-011-1806-z$.

Ogawa S, Decker EA, McClements DJ. 2004. Production and characterization of $\mathrm{o} / \mathrm{w}$ emulsions containing droplets stabilized by lecithin-chitosan-pectin mutilayered membranes. J Agr Food Chem 52: 3595-3600. DOI: 10.1021/jf034436k.

Phan TT, Attaphong C, Sabatini DA. 2011. Effect of extended surfactant structure on interfacial tension and microemulsion formation with triglycerides. J Am Oil Chem Soc 88: 12231228. DOI: $10.1007 / \mathrm{s} 11746-011-1784-1$.

Qian C, Decker EA, Xiao H, McClements DJ. 2011. Comparison of biopolymer emulsifier performance in formation and stabilization of orange oil in water emulsion. J Am Oil Chem Soc 88: 47-55. DOI: 10.1007/s11746-010-1658-y.

Shen Z, Udabage P, lko B, Augustin MA. 2005. Characterization of fish oil-in-water emulsions using light-scattering, nuclear magnetic resonance, and gas chromatography-head- 
space analyses. J Am Oil Chem Soc 82: 797811. DOI: 10.1007/s11746-005-1146-6.

Tadros TF. 2013. Emulsion Formation, Stability, and Rheology. In Tadros TF (ed), Emulsion Formation and Stability. $1^{\text {st }}$ Ed. 1-75. WileyVCH Verlag GmbH \& Co. KgaA, Weinheim.

Tan CP, Nakajima. 2005. $\beta$-carotene nanodispersions: preparation, characterization and stability evaluation. Food Chem 92: 661-671. DOI: 10.1016/j.foodchem.2004.08.044.

Wan J, Zhang W, Jiang B, Guo Y, Hu C. 2008. Separation of individual tocopherols from soybean distillate by low pressure column chromatography. J Am Oil Chem Soc 85: 331 338. DOI: $10.1007 / \mathrm{s} 11746-008-1198-x$.
Wang G, Wang T. 2008. Oxidative stability of egg and soy lecithin as affected by transition metal ions and $\mathrm{pH}$ in emulsion. J Agr Food Chem 56: 11424-11431. DOI: 10.1021/jf8022832.

Widjajanti ELFX, Tutik RP. 2004. Penentuan konsentrasi misel kritis lesitin secara turbidmetri. J Kimia 2: 105-115.

Yuan Y, Gao Y, Zhao J, Mao L. 2008. Characterization and stability evaluation of $\beta$-carotene nanoemulsions prepared by high pressure homogenization under various emulsifying conditions. Food Res Int 41: 61-68. DOI: 10. 1016/j.foodres.2007.09.006. 